
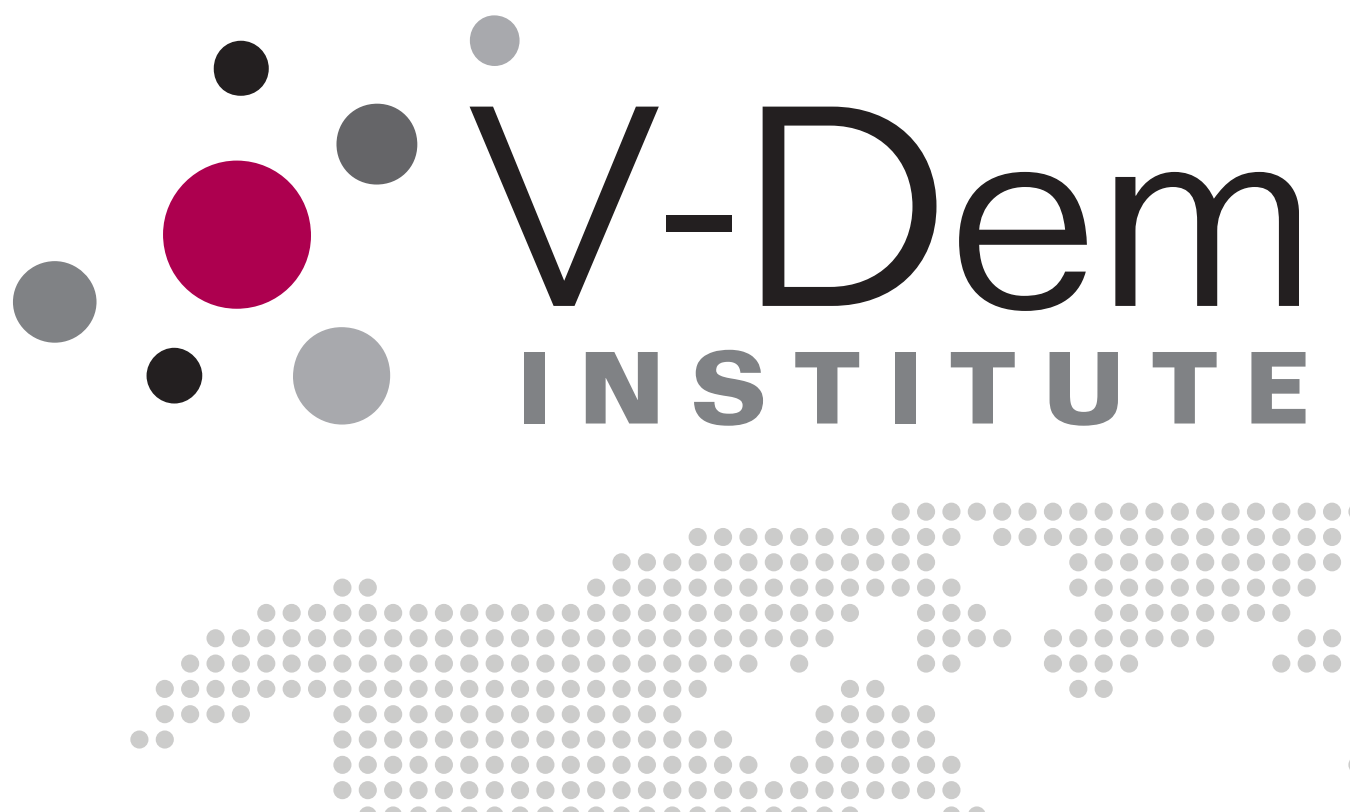

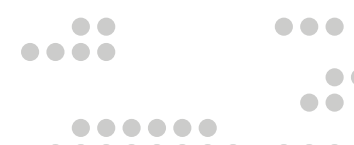

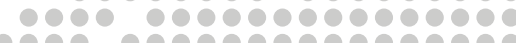
O

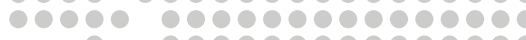
$1000 \quad 000000000000000000$

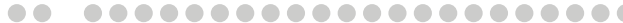
4

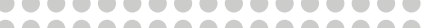
resere

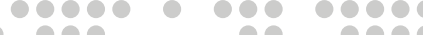
1000000000000000

Institutional Subsystems and the Survival - 00090909090 690000000 of Democracy: Do Political and Civil Society Matter?

Michael Bernhard, Allen Hicken, Christopher Reenock and Staffan I. Lindberg 00000000000000 1000000000000000000

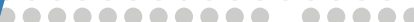

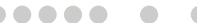

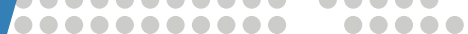

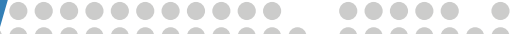

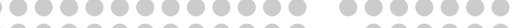

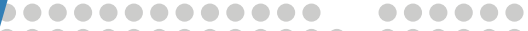

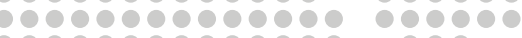
10000000000000 1900090909090090

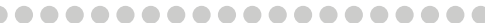

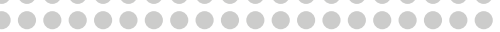

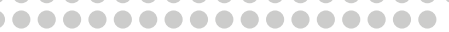
0000000000000 00000000000000 000000000000 000000000000

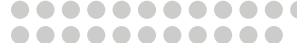
6090900000 20000000000

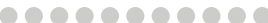
00000000000

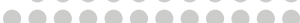

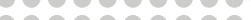

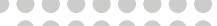
-

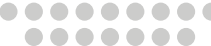

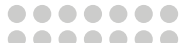
10000000 0000000 000000 1000 200000 1000 100 1000 10 00 90 100 100 80 
Varieties of Democracy (V-Dem) is a new approach to the conceptualization and measurement of democracy. It is co-hosted by the University of Gothenburg and University of Notre Dame. With a V-Dem Institute at University of Gothenburg that comprises almost ten staff members, and a project team across the world with four Principal Investigators, fifteen Project Managers, 30+ Regional Managers, 170 Country Coordinators, Research Assistants, and 2,500 Country Experts, the V-Dem project is one of the largest-ever social science research-oriented data collection programs.

Please address comments and/or queries for information to:

V-Dem Institute

Department of Political Science

University of Gothenburg

Sprängkullsgatan 19, PO Box 711

SE 40530 Gothenburg

Sweden

E-mail: contact@v-dem.net

V-Dem Working Papers are available in electronic format at www.v-dem.net.

Copyright (C) 2015 by authors. All rights reserved. 


\title{
Institutional Subsystems and the Survival of Democracy: Do Political and Civil Society Matter?*
}

\author{
Michael Bernhard \\ University of Florida \\ Allen Hicken \\ University of Michigan \\ Christopher Reenock \\ Florida Satte University \\ Staffan I. Lindberg \\ University of Gothenburg
}

\footnotetext{
* Paper prepared for presentation at the annual meeting of the Midwest Political Science Association, April 16-19, Chicago IL. Paper prepared for presentation at the annual meeting of the Midwest Political Science Association, April 16-19, Chicago IL. This research project was supported by Riksbankens Jubileumsfond, Grant M13-0559:1, PI: Staffan I. Lindberg, V-Dem Institute, University of Gothenburg, Sweden
} 


\begin{abstract}
How do two central institutional subsystems of democracy - party systems and civil society - affect the persistence of democratic regimes? Despite the ability of each of these institutions to provide sources of countervailing power that make politicians accountable and thus responsive, distributionist accounts of democratic breakdown provide few insights on how such institutions may encourage parties to reach accommodation. We argue that these institutions provide credible threats against anti-system activities that would otherwise threaten the democratic compromise. We test our argument with newly available data from the Varieties of Democracy (V-Dem) project by analyzing all episodes of democratic breakdown from 1900-2001. Using a split population event history estimator, we find evidence that these institutions not only forestall the timing of breakdowns among transitional democracies but also that a strong party system is critical to setting democratic regimes on the path of consolidation.
\end{abstract}




\section{Introduction}

How do two central institutional subsystems of democracy - party systems and civil society - affect the persistence of democratic regimes? If like Dahl, we understand democracy as a system of government that in comparison to other forms of rule is more responsive to the preferences of citizens, then the ability of citizens to steer the political system to provide a set of acceptable outcomes is an essential part of maintaining an effective and legitimate government. Civil and political societies play several essential roles in this process. First, they are sites through which citizen preferences are formulated and aggregated. Second, these are the realms via which citizens overcome collective action problems and through which representation is secured. Finally, through both resistance to state actions and the contesting of elections, they are sources of countervailing power that make politicians accountable and thus responsive.

Despite this, recent distributionist accounts do not foreground the role of institutions. At one extreme Przeworski has gone so far as to claim that institutions are endogenous. He suggests that they are merely a product of the same material and sociological conditions that explain democracy (Przeworski, 2004, pp. 531-2). Such claims are not outlandish given many of the early null findings on the subject of institutions and survival built on works as foundational as Linz work on the perils of presidentialism for democratic breakdown (1978) and Sartori's work on the centrifugal effects of polarized pluralism (1976), also see Linz 1978). Attempts to test the impact of presidentialism or the large numbers of parties associated with polarized pluralism on democratic survival only infrequently and inconsistently attain levels of conventional significance. The collective weight of these studies leads to the conclusion that these particular institutions are irrelevant to survival in general but may matter contingently in very specific contexts ( Mainwaring \& Shugart, 1997; Sing, 2010; Aleman \& Yang, 2011; Bernhard, Nordstom \&Reenock 2001; Przeworski, Alvarez, Cheibub, \& Limongi, 2000; Cheibub, 2007; Madea 2010; Mainwaring \& Pérez-Liñán, 2014; Svolik, 2008; Lai \& MelkonianHoover, 2005; Sing 2010).

Our approach to the question of how institutions shape democratic survival builds on earlier attempts to situate the role of institutions in easing distributional dilemmas. We focus on how two institutional subsystems — the party system and civil society—shape the ability of actors to hold each other accountable for attempted defection from democratic norms and practices. Existing work on

party systems and democracy have tended to focus on the number of parties as a proxy for 
polarization, with the mixed results described above. However, we argue that other dimensions of the party system, namely, the degree of party system institutionalization, bear much more directly on the ability of actors to overcome commitment problems. Where civil society has been included in discussions of democratic longevity it has tended to focus on the roles social mobilization and social capital. We build on this work to argue that perhaps civil society's greatest positive impact on democratic survival comes when it serves as a credible threat against attempts to undermine democracy. Our contribution is to move away from individual institutions and focus on larger meso-level institutional subsystems and focus on how they help to foster the conditions that make adherence to the democratic rules of the game self-enforcing (Przeworski, 1991). (North, Summerhill, \& Weingast, 2000).

The rest of the paper proceeds as follows. In the next section, we discuss how institutions affect the capacity and incentives of actors to overcome the collective action problems inherent in democratic government. We then discuss how the party system and civil society shape the actors' ability to overcome commitment problems, and thus affect the probability of democratic durability. We then discuss our empirical strategy for testing out hypotheses, including the use of a novel dataset from the newly available V-Dem project on civil society and party systems. Finally, we discuss our findings and their implications.

\section{Institutions and Collective Action Problems}

One of the chief ways institutions are hypothesized to affect democratic longevity is by providing actors the means to overcome collective action problems. Specifically, institutions are expected to shape actors' capacity to overcome bargaining, monitoring and coordination problems. Standard distributional models of regime instability, for example, emphasize that the foundation of democratic durability is stable bargains between citizens and the elite, and between different factions within the elite. In such models, bargaining failure between competing parties is a fundamental trigger for regime collapse. Whether competition occurs between elite coalition members or between elites and citizens, bargaining failures over rent distribution, public goods or tax burdens can raise potential threats to a regime's tenure (Acemoglu and Robinson 2005; Przeworksi 2005; Svolik 2012). With respect to democratic regimes, divergence between actors' policy preferences and the lack of credible threats to punish potential defectors from the democratic compromise are both linked to regime fragility. 
For example, by reducing preference divergence, both higher income levels (Przeworski, 2005) and moderating income inequality (Acemoglu \& Robinson, 2006; Boix, 2002) have the potential to ease the prospect for bargaining failures. As incomes rise and relative income disparity wanes, the set of jointly preferred policy options between competing actors grows, incentivizing stable democratic outcomes. As differences in preferences converge and the bargaining space between parties increases, actors find themselves better able to tolerate the policy choices of others.

The potential for a sustained democratic outcome, however, is also conditional on whether actors have credible threats to impose costs on other actors for defection. The most common conceptualization of these punishment mechanisms is the governing party's threat to repress or the opposition's threat to rebel. When such threats are sufficiently credible, actors' expected utility of pursuing anti-system tactics decline.

Curiously, early on, these distributional models of democratic durability were relatively silent on the role of institutions in encouraging stable regime outcomes. Indeed, Przeworski (2005) rather controversial claim that outside of their use in declaring the winner of an election that 'institutions' were unnecessary to secure the democratic compromise is emblematic. This view of institutions and regime stability flew in the face of the earlier theories that emphasized the value of particular institutions in prolonging both autocratic and democratic regimes. Early analytic models often made assumptions about the informational environment, the availability of punishment mechanisms and the fixed nature of collective action and coordination dilemmas that did not allow a role for institutions.

More recent work has begun to consider precisely how institutions might affect regime dynamics. By altering the distribution of power, improving the informational environment, providing credible threats or resolving coordination dilemmas, certain institutions may enhance the potential for cooperation among actors party to the democratic compromise. Important work has been done in this regard in thinking about the role of legislatures under electoral autocracy. Legislatures can either act as forums to negotiate policy concessions that can coopt or, at least, keep opposition political forces quiescent (Ghandhi 2008), or they can aid in resolving informational problems between elite coalitions and the autocratic incumbent (Boix and Svolik 2014). From both of these perspectives, the nominally "democratic" institution of a legislature acts as a prophylactic against autocratic collapse. 
Under democracy, institutions can have similar beneficial effects for regime survival. Federalist systems, for example, may provide insulation to vulnerable minority groups or regional elites, thereby enhancing the prospects of securing a stable democratic outcome (Boix 2002) (North, Summerhill, \& Weingast, 2000). Independent courts may buttress the democratic compromise. By resolving fundamental monitoring and coordination activities between winners and losers, independent courts can signal when a violation of the democratic compromise is legitimate, thereby avoiding unnecessary threats to the democratic regime's survival (Reenock, Staton and Radean 2014).

In a similar way we argue that institutionalized party systems and robust civil society offer important safeguards against anti-system activity. Building on this literature we contend that when contending elites and the organized citizenry are able to credibly threaten sanctions against anti-system behavior this makes the democratic compromise self-enforcing. We highlight the role of civil society and party systems as key. Lying at the nexus of elite-citizen relationships that party systems and civil society, separately and jointly, affect the ability of citizens and elites to credibly threaten sanction against potential democratic defectors. They are essential to establishing "credible bounds on the behavior of political officials" with regard to the democratic political order (North, Summerhill, \& Weingast, 2000, p. 24). Our argument extends the logic of this reasoning by arguing that that the establishment of such credible bounds goes beyond constitutions, rights, and a sense of legitimacy (though the first two are necessary and the third helps to ease the burden of establishing such bounds) by introducing the deterrent capabilities of counterelites and organized publics into the calculus of what produces durable democracy.

\section{Party Systems}

A number of scholars have drawn a direct connection between party system institutionalization and the consolidation or survival of democracy. In institutionalized party systems parties have strong, stable bases of support, robust party organizations, and party labels that are distinct and valuable to both voters and candidates. ${ }^{1}$ By contrast, weakly institutionalized party systems are characterized by

\footnotetext{
${ }^{1}$ The existing literature defines institutionalization in a variety of ways — though Mainwaring and Scully's (1995) definition remains the most influential. The common elements of these definitions include the following (Hicken and Kuhonta 2014): Stability of interparty competition, parties viewed as legitimacy by major actors, value infusion, and organizational routinization. For our purposes value infusion and organization routinization are of the greatest interest. For more on how to define institutionalization see, for example, Huntington 1968; Welfing 1973; Panebianco 1988;
} 
fleeting parties which lack stable bases of support and enter and exit the system frequently. Within these ephemeral parties, organization is weak and party platforms are poorly articulated and indistinct. Why would we expect the level of institutionalization to be causally linked with democratic survival? To date, two general arguments have been advanced in the literature.

The first highlights the role of parties as both the symbols and machinery of democracy. Parties in institutionalized systems provide a stable means for channeling the interests of social groups and a collective way for citizens to hold government vertically accountable. Where parties fail to perform these functions, as in less-institutionalized party systems, disillusionment and disaffection with both political parties and with the democracy itself is often the consequence. ${ }^{2}$ This can open the door for anti-system forces, including the military or populist politicians (Mainwaring and Torcal 2005; Schamis 2006; Roberts 2007; Kaufman 2008; Ufen 2008; Doyle 2011). ${ }^{3}$

While party system institutionalization may not be necessary for the democratic consolidation (Toka 1997; Markowski 2001) the presence of institutionalized parties seems to increase the chance of democratic consolidation (Dix 1992; McGuire 1997; Wallis 2003; Lewis 2006) and decrease the chance of democratic breakdown (Skatch 2005; Ufen 2008). Basedau (2007) and Basedau and Stroh (2013) dissent from this position, failing to find a strong relationship between institutionalization and democratic stability. Others have argued that the relationship between institutionalization and consolidation or stability is non-linear. Starting at a low level an increase in institutionalization increases the prospects for democracy. However, beyond a certain point greater institutionalization becomes "partyarchy" (Coppedge 1994) and can actually undermine democratic stability (Stockton 2001; Roberts 1998; Bertoa 2009).

A second set of scholars considers the indirect effects of party system institutionalization on democratic stability. Led by Mainwaring (1998; 1999; Mainwaring and Torcal 2006) this work establishes the correlation between the level of institutionalizations and the quality of democracy. Higher levels of institutionalization are associated with a higher quality of democracy while low levels of institutionalization are associated with low quality democracies (Osei 2012; Kneuer 2013; Reidl 2014). Relatedly, a number of studies associate institutionalization with better democratic

Mainwaring and Scully 1995; Levitsky 1998; Randall and Svasand 2002; Ufen 2008; Hicken 2011; Hicken and Kuhonta 2014.

${ }^{2}$ Doyle, for example, finds that low levels of party system institutionalization is associated with greater support for antisystem populist candidates (2011).

${ }^{3}$ Weyland (2009) notes that many of these studies face serious endogeneity challenges. 
governance, including more programmatic representation, greater stability of interests, better accountability, and more attention to public goods (e.g Mainwaring and Torcal 2006; Tóka 1997).

Our argument is closest to the democratic disillusionment story, but rather than focusing on the support for democracy among citizens, we are concerned with the potential constraints on would-be anti-democratic defectors. The argument, stated simply, is this -- leaders in institutionalized party systems are more like to face organized opposition if they begin to retreat from fundamental democratic principles compared to leaders in weakly institutionalized systems. Party leaders in institutionalized systems, with their reliable bases of support, robust organizational capacity, and longer time horizons have the capacity and incentive to overcome collective action problems in response to attempts by their opponents to defect from the democratic bargain. The form of this organized opposition can be both electoral and extra-electoral. From the perspective of a would-be defector in an institutionalized system, the likelihood of strong, organized opposition from partisan opponents is much more likely to represent a credible threat. It increases the expected costs of defection, while decreasing the probability that such a move will succeed. In short, the expected utility of trying to subvert democracy should be lower, ceteris paribus, in institutionalized party systems.

By contrast, the expected costs of defection for leaders in weakly institutionalized systems is much lower. Leaders in such systems are more likely to face weaker opposition with rampant intra-party collective action problems, short time horizons, indistinct messaging, and reputation shortfalls. As a result parties fail to present a credible threat to a leader contemplating a retreat from fundamental democratic principles. Or, stated differently, the expected utility of defection is higher in weakly institutionalized party systems, ceteris paribus.

To summarize, if party system institutionalization allows for electoral sanction against aggressive anti-system tactics, then leaders, in expectation of oppositional electoral pressures, will be less likely to pursue such tactics. Leaders in under-institutionalized party settings, facing a less well-organized and identified opposition, are less likely to face credible countervailing pressures. As a result they will be less likely to be constrained from taking anti-system measures. Oppositions will be similarly affected. When party system institutionalization is strong, oppositions have an incentive to pursue policy change via systematized electoral competition. Due to the strong expectations of electoral punishment, oppositions will be less likely to pursue anti-system tactics. Accordingly, ceteris paribus, 
party system institutionalization ought to be positively related to parties' incentives to respect the democratic compromise.

\section{Civil Society}

Like party system institutionalization, civil society is a complex concept with multiple dimensions. We understand civil society as "an organizational layer of the polity that lies between the state and private life. Civil society is composed of voluntary associations of people joined together in common purpose..." in pursuit of civic goals (V-Dem, 2014, pp. 183-184). To elaborate - civil society is regulated by the state, but must be sufficiently autonomous from it. The absence of such autonomy abrogates its existence. The fully etatized top-down forms of social organizations common in many authoritarian regimes are not civil society but transmission belt organizations that allow the state to control society. Civil society is populated by groups of citizens organized to act in pursuit of common goals and interests. Such civil society organizations (CSOs) include interest groups, labor unions, social movements, professional associations, welfare organizations, etc. They are distinguished from political society (organizations primarily focused on contesting and taking state power) and organized private activity (e.g. spiritual or economic). ${ }^{4}$

There are two basic approaches in the literature to the issue of civil society and democracy, the neoWeberian and the neo-Tocquevillian. Both suggest that a more developed civil society should promote democracy, though there is some dissent from this consensus. They are also distinct in that the former is a structural/institutional theory and the latter, cultural. The return of civil society as an important concept in comparative politics was sparked by the reemergence of resistance to harsh forms of dictatorship by popular movements and organizations in the 1970s. Early neo-Weberian proponents of the concept included Jacques Rupnik (1979) and Andrew Arato (1993) in their analyses of political opposition in communist Poland, and Alfred Stepan (1985) who applied the concept to resistance to the military regime in Brazil. The idea of social mobilization as a critical

\footnotetext{
${ }^{4}$ Several kinds of organizations should not considered part of civil society: (a) forced membership organizations in etatist regimes, (b) public or private firms, (c) churches or other institutions devoted to the practice of spirituality, and (d) criminal organizations. These exclusions do not mean that groups associated with firms (owners or workers) or with religious life cannot found civic associations. Obviously, if they do, they are considered part of civil society. Thus we are not excluding trade unions, industrial lobbies, or organizations that follow religious teachings as a motivation for civic engagement. With regard to religious organizations - saving souls is private; social engagement is civic. Religious inspired groups who pursue public policy in line with their beliefs are clearly part of civil society. With regard to economic activity - production is private; union or industry lobby activities to affect public policy are part of civil society.
} 
moment in democratic transition was also taken up later by prominent theorists of regime change as well (O'Donnell \& Schmitter, 1986) (Przeworski, 1991).

After transition, an active and organized civil society is essential to checking prerogative state power and keeping politicians accountable to the electorate and aware of social pressure between electoral episodes (Linz \& Stepan, 1996; Ekiert \& Kubik, 1998). A great deal of work has been done on the weakness of civil society in the postcommunist region as a potential threat to sustained democracy in the region (Howard, 2003; Bernhard \& Karakoç, 2007; Pop-Eleches \& Tucker, 2013). ${ }^{5}$ However, there is no consensus regarding the salutary effects of civil society on democracy. A number of authors have talked about how highly mobilized civil societies in particular cases can provide a means for authoritarian challengers to undermine and weaken democracy or even use civil society organizations to take control of the state (Berman, 1997; Chambers \& Kopstein, 2001; Riley, 2010).

The origins of the neo-Toquevillian school lies in the civic culture tradition (Almond \& Verba, 1963) and the study of the impact of political values and attitudes on democracy. The key transitional figure in the move from civic culture to civil society in this tradition is Putnam who demonstrated a link between associational life, trust, and what was first labelled social capital in his study of regional differences in Italy (1993). Whereas, Putnam himself has rarely used civil society as a central concept, preferring to talk about civic engagement and the building of social capital and community (Putnam R. D., 2000), others building on his work have readily done so (Skocpol, 2011; Newton, 2001; Edwards \& Foley, 1998). ${ }^{6}$ Associational life, an active and dense civil society, is seen as producing interpersonal trust and other forms of social capital which promote democratic performance and longevity. Within this line of inquiry there are dissenters as well, who argue that the causal connections specified are spurious and thus cast doubt on the connection between culture and democracy, and argue that the causal direction runs from democratic institutions to trust (Encarnación, 2003; Seligson \& Mueller, 1994; Rothstein, 2005).

Despite ongoing disputes over the role of civil society in the maintenance of democracy, the weight of opinion argues that its impact is positive. We will seek to show that a civil society that is

\footnotetext{
${ }^{5}$ Ekiert and Kubik dissent from this view and point to Poland as a case where a mobilized civil society has worked as surrogate for a political society that was weak and perennially crippled early in the post-transition phase of democratization.

${ }^{6}$ Also see, for example, the articles in Skocpol and Fiorina (1999). Others active in the values and democracy literature such as Ronald Inglehardt and Christian Welzel have also been reticent to fully embrace the language of "civil society"(2005).
} 
unencumbered by repressive state regulation and in which citizens are engaged has an overall positive effect on the duration of democratic regimes despite the small number of well-documented cases in which civil society mobilization has played a role in democratic breakdown. We believe that the effect will be overwhelmingly positive in the preponderance of cases. However, it is possible that an over-mobilized civil society in the absence of a well-institutionalized party system to channel its activism in a constructive direction may complicate the matter (Berman, 1997; Huntington, 1968). Such considerations also open up the possibility that the relationship between democratic stability and the strength of civil society may be non-linear, with both low and high levels of strength posing a threat (piece which Chris read and we talked about).

Like our argument about party systems, we are concerned with the way that civil society might act as a constraint on leaders who are tempted to defect from democratic norms and ideas. Our argument proceeds as follows. Highly developed civil societies offer the potential for popular social engagement. From a neo-Weberian perspective, higher levels of social engagement in politics provide popular pressure on political elites and state officials. The presence of this popular pressure, whether real or potential, incentivizes democratic leaders and oppositions to work within the democratic framework to resolve their policy differences. Under such systems, there exist credible threats against possible violations of fundamental democratic principles. In the absence of this credible threat, one or more actors may find the allure of pursuing anti-system tactics sufficiently attractive, putting the democratic compromise at risk. From a neo-Tocquevillian perspective civil society should both build trust and political competence facilitating the ability of competing elites and the governed to resolve bargaining dilemmas. In either case, ceteris paribus, robust civil society ought to be positively related to actors incentives to respect the democratic compromise.

\section{Empirical Analysis}

Exploration of the link between party systems, civil society and democratic durability has been hampered up to now because of the difficulty of collecting cross-national data on these areas of the polity over a long period of time. However, because of the new data available through the "Varieties of Democracy" project, this is now possible. V-Dem data on party institutionalization and civil society is available for all states from 1900 to 2012 - more on these data below.

Our empirical strategy, then, is to isolate the effect of civil society and party institutionalization, using these V-Dem measures, on democratic regime stability. To this end, we will examine these 
relationships in the context of event history analysis, modeling a democratic regime's hazard of experiencing breakdown as a function of civil society and party institutionalization and a set of controls. We will consider both standard event history estimators as well as split population event history estimators that allow us to decompose the influence of covariates on both the likelihood that a regime is consolidated and on the timing of breakdowns among transitional regimes (Svolik 2008).

In our set up, we will consider every democratic regime from 1900 to 2001 . We begin in 1900 due to the data availability on the V-Dem measures. We end in 2001 not due to any data constraint but rather to allow us to directly compare our findings with those of Svolik (2008). We use the democratic regime event history dataset by Boix, Miller and Rosato (2013) to classify the onset and collapse of our democratic episodes. Democratic regimes that break down prior to 2001 are coded as reversals, and those that experienced no breakdown by the end of our temporal window are coded as right censored. In this subset of the data, we have 3157 country years of data, with 167 episodes of democracy, 60 of which end in breakdown.

\section{Estimation}

To estimate our models we will use both standard and split-population event history estimators. The standard estimator presumes that all democratic episodes are vulnerable to experiencing a breakdown and models the effect of covariates on this likelihood. We employ two standard estimators: the Weibull and Log-log parametric models. The Weibull model assumes a monotonic baseline hazard rate and possesses the proportional hazards property, where the effect of a covariate induces a change in the hazard that is proportional to baseline hazard and this change is presumed to be constant over time. The Log-log parameterization is more flexible in that it allows for nonmonotonic hazard rates and avoids the proportional hazards assumption. We will estimate both of these models with a Gamma shared frailty parameter to account for unobserved heterogeneity across repeated observations.

The split population estimator is Svolik's split population event history model (2008). It, as well, includes both a Weibull and Log-log parameterization of the survivor distribution. This splitting estimator does not assume that all democratic episodes are vulnerable to a breakdown. Rather it assumes that the population of democratic episodes consists of two subsets: consolidated democracies and transitional ones. The power of such splitting estimators is to allow the analyst to assess the distinct impact of covariates on each of these processes by estimating each process jointly. 
The result is to estimate two models. The first characterizes the effect of covariates on the timing of breakdown among transitional regimes. The second characterizes the effect of covariates on the probability of democratic regime being consolidated.

In our case, the benefit of this splitting estimator is that it will allow us to assess whether civil society and party institutionalization resources help consolidate democracies, better insulate transitional democracies from breakdown, or both.

\section{Main Variables}

Here we review the operationalization and measurement of our key independent variables and discuss our research strategy. Our variable Party System Institutionalization or PSI is an index of 5 indicators from V-Dem dataset, and is designed to capture the extent to which party systems are characterized by parties with distinct programmatic identities, strong ties to groups of voters, and robust organizations. (This corresponds with the internal dimension the PSI concept—see Hicken 2014.) The 5 indicators are as follows:

- Party organizations (v2psorgs): How many political parties for national-level office have permanent organizations?

- Party branches (v2psprbrch): How many parties have permanent local party branches?

- Party linkages (v2psprlnks): Among the major parties, what is the main or most common form of linkage to their constituents?

- Distinct party platforms (v2psplats): How many political parties with representation in the national legislature or presidency have publicly available party platforms (manifestos) that are publicized and relatively distinct from one another?

- Legislative party cohesion (v2pscohesv): Is it normal for members of the legislature to vote with other members of their party on important bills?

We operationalize civil society using an index of indicators from the V-Dem data, called the Core Civil Society Index (CCSI). CCSI was designed to measure the robustness of civil society, understood as the extent to which civil society organizations can organize free of constraints by the state and the extent to which the citizenry actively involved in participation in civil society organizations. 
We measure this as an index of the following three V-Dem indicators:

- CSO Repression (v2csreprss): Does the government attempt to repress civil society organizations (CSOs)?

- CSO Entry and Exit (v2cseeorgs): To what extent does the government achieve control over entry and exit by civil society organizations (CSOs) into public life?

- CSO Participatory Environment (v2csprtcpt): Which of these best describes the involvement of people in civil society organizations (CSOs)?

Factor analysis reveals that PSI loads on these five indicators and CCSI loads on these three indicators. The indices consist of the point estimates from a Bayesian factor analysis (BFA) that has then been converted to a normal cumulative density function. Each of these variables has been scaled from 0 to 1 to ease interpretation.

Figure 1 below displays two panels for each variable across the democratic regimes in the data that never experience a breakdown and those that do. Critical for our application, is the variance in both of these institutions among these sets of democracies.

The panels display the distribution across these cases. Each of the variables are left-skewed for both sets of regimes, with most democracies clustering at fairly highly developed civil societies and institutionalized party systems. For democracies that never experience a breakdown, the mean value civil society is .856 with a standard deviation of .132, while the mean value for party institutionalization is .815 with a standard deviation of .128 . There is considerably more variation in

Figure 1. Histogram of Civil Society and Party Institutionalization over Regime
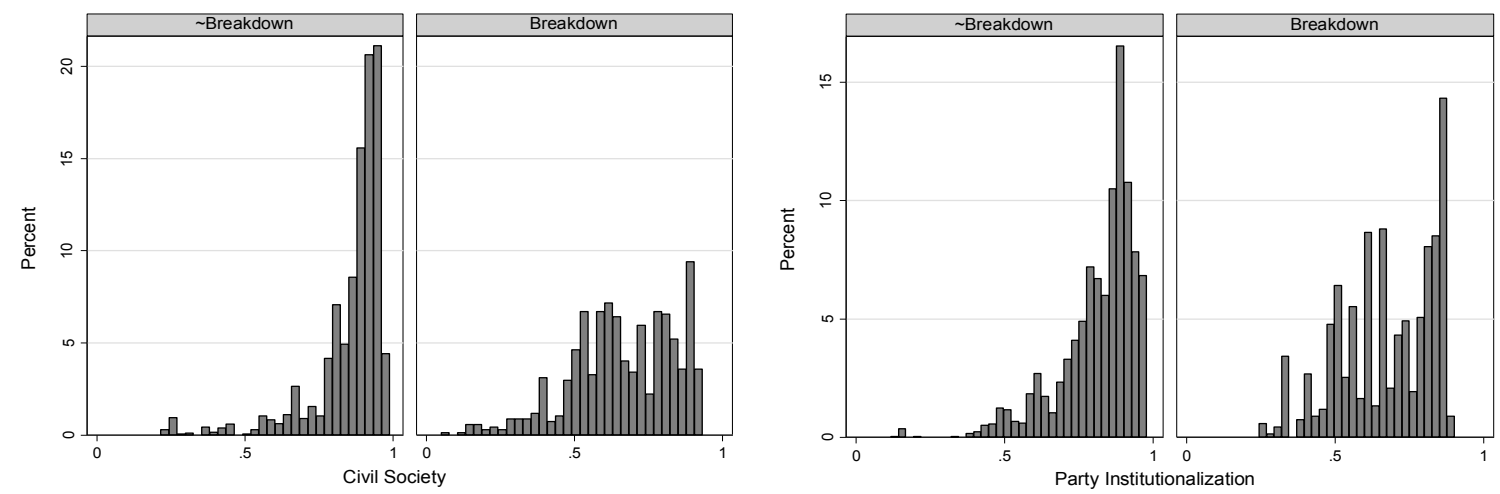
the data among those democracies that have experienced a breakdown. For democracies that have broken down, we see, predictably, the mean value of civil society is lower at .662 with a standard deviation of .175 , while the mean value for party institutionalization is .672 with a standard deviation of .158 .

We should also note that the pattern of these data is one where the variance is cross-sectionally dominant rather than within the democratic episode. For the large majority of cases civil society and party institutionalization are democratic resource that take shape at the beginning of an episode, partially shaped by their authoritarian legacies (Bernhard \& Karakoç 2007; Hicken and Kuhonta 2014; Rueschemeyer, Stephens, \& Stephens 1994) and partially shaped by dynamics of their transitions. On average, the relative size of the between democratic episode variance to the within democratic episode variance is on the order of $4.64 \mathrm{x}$ larger. This is a stark difference when compared to the variance of GDP per capita among our democratic episodes. GDP per capita is more balanced, with a slightly greater within episode variance by a ratio of 1.08. As a result, the variance that we will exploit in this investigation is that which varies between our democratic episodes.

\section{Identification}

Before moving on to the multivariate analysis, we consider here two additional concerns. Can the relationship between civil society, party institutionalization and regime survival be identified? We believe that it can be. First, theoretically, these institutional resources experience natural breaks with their past at the point of a democratic transition. While not a perfect discontinuity, they are perhaps the closest that we may see in international observational data. ${ }^{7}$ The nature of party politics during authoritarian interludes can also shape the party system that follows after a transition to democracy. Decisions by autocrats - whether to outlaw all parties, form a new ruling party, or coopt existing parties - can cast a shadow that extends beyond the democratic transition and influence the

\footnotetext{
${ }^{7}$ Under extreme forms of authoritarianism, like communist post-totalitarianism we see party-states enforcing a monopoly of political organization (Howard 2003), whereas under more conventional authoritarian regimes we see more toleration of social pluralism but repression precluding the kind of political pluralism that leads to democratic responsiveness (Linz \& Stepan, 1996). With liberalization and relaxation of repression in the classic model of transition we see the (re)emergence of civil society (Przeworski, 1991) (O'Donnell \& Schmitter, 1986). There are also patterns where the mobilization of previously dormant civil societies in what turn out to be the late stages of authoritarianism play a crucial role in the opening of democratizating sequences as well (Bratton \& Van de Walle, 1997; Adler \& Webster, 1995; Bernhard, 1993) (Fernandes, 2015). Following such phases party system (re)emerge as elections are put on the table or restrictions of parties are removed under forms of electoral authoritarianism (Schedler, 2013; Reidl 2014).
} 
probability that institutionalized parties emerge under democracy (Geddes and Franz 2007, Hicken and Kuhonta 2014). Last, as we note above we see little within case variation in either party institutionalization or civil society over the length of a typical democratic episode, limiting the potential case the hazards that a regime may face will in turn influence either of these institutions.

Second, might these data series be driven by economic development? Perhaps. Let's consider this possibility. We first considered the zero order correlations of civil society and party institutionalization with GDP per capita over the entire democratic episode data. These correlations are .46 and .53 , respectively. These relatively high correlations suggest that perhaps wealth is indeed a driving force behind the development of these institutions. But what of their dynamic relationship? We know from above that civil society and party institutionalization vary little within a democratic episode and that wealth, on average, exhibits a strong positive trend. How then do these correlations vary over the lifetime of the average democracy? Early, in a democracy's life, the correlations between wealth and our institutions are much weaker. In fact, in the first year, they are .11 and .38 respectively. These positive correlations slowly grow over a democratic episodes tenure.

Figure 2 below illustrates nicely a few common patterns in these data. We consider the democratic episodes of Chile (1932-1973) and Ecuador (1979-2000). Each of the series display the within case stability for civil society and party institutionalization that we observe among most democratic episodes. Each of these cases be in with civil society and party institutionalization at relatively high levels, particularly for developing democracies, and remain there for the duration of the episode. The Chilean case also demonstrates the familiar pattern that we see between development and our two institutional variables. Early in the series GDP is relatively lower despite civil society and party

Figure 2. GDP, civil society and party institutionalization over time for Chile and Ecuador
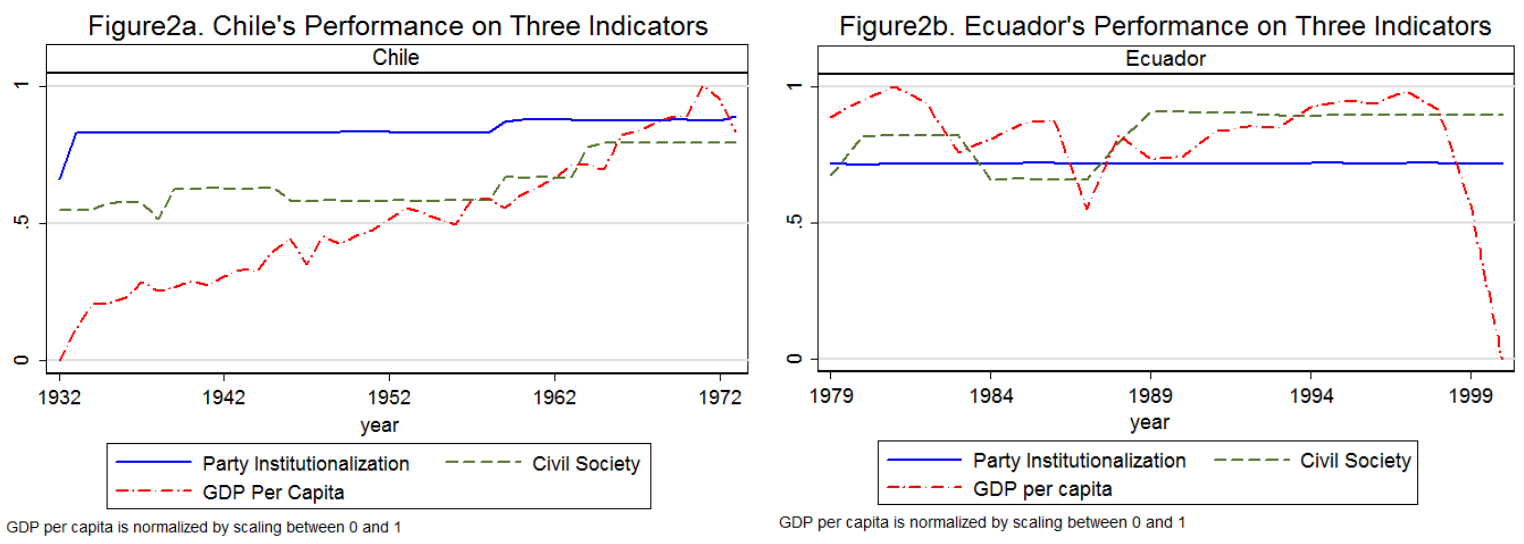
institutionalization being relatively more developed. As the country's economy grows over the next four decades we might expect a stronger correlation between GDP and these two measures. Last, it is important to note that each of these episodes ended in Democratic breakdown. However, compared to other cases a breakdown in our data, these two cases endured relatively long before there democratic collapse and possessed relatively higher investments in civil society and party institutionalization, offering suggestive evidence that these institutions may have provided decades worth of insulation from potentially destructive anti-system elements.

We can also consider the relative distribution each of our institutions with GDP per capita across instances of Democratic breakdown. Figure 3 below displays this relationship for civil society and party institutionalization.

Figure 3. GDP per capita, Civil Society and Party Institutionalization across
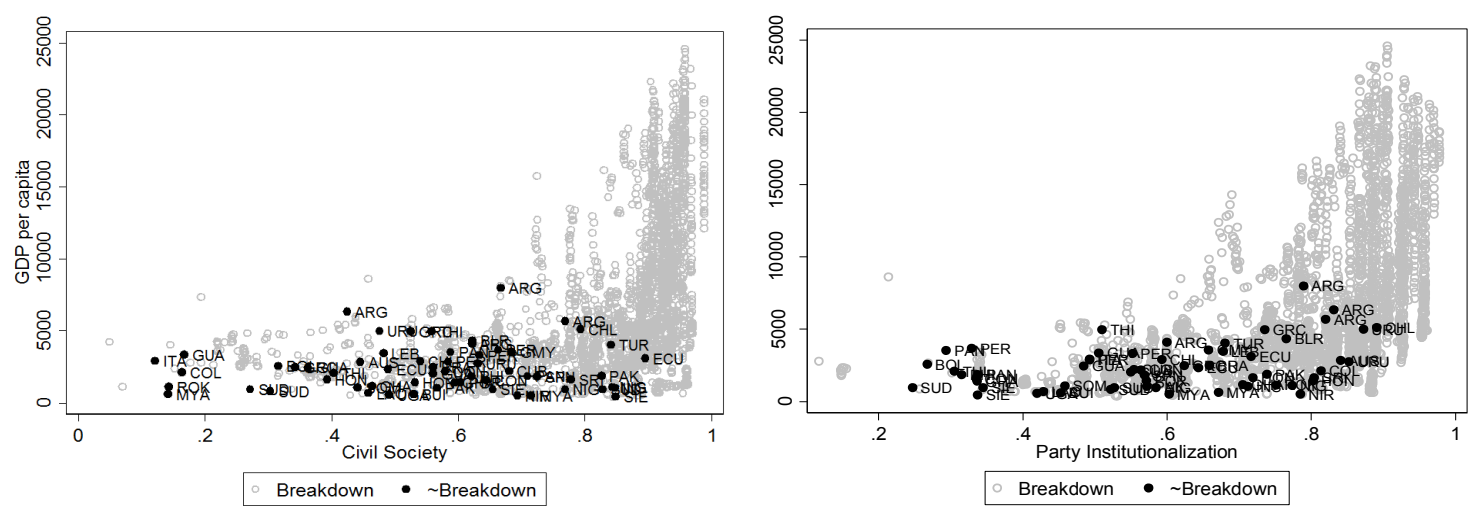

Overall we see the moderate correlation between each institution and wealth, with the standard hockey stick relationship displayed. Important for our argument is that instances of democratic breakdown must not be clustered randomly across each of these institutional features. Rather, we would expect to see a relative absence of democratic breakdowns on the far right-hand side of the graph, particularly for those cases at or above the mean on both civil society and party institutionalization. Indeed, we see descriptive evidence of this relationship. We see hardly any cases of breakdown at sufficiently high levels of society and party institutionalization, even among relatively poor states. We should note that this relationship is not quite as strong for party institutionalization, given that we do not observe relatively poor states with extremely strong party institutionalization. The effects of these institutions do not seem to be completely captured by a democracy's economic development. The overall pattern offers suggestive support for our 
argument — civil society and party institutionalization would appear to be offering some element of protection against anti-system forces.

\section{Evidence from Multivariate Analysis}

Before presenting the results of the multivariate analysis, we first display to Kaplan-Meier plots for civil society and party institutionalization, respectively. We coded each variable into quartiles and then estimated the survival function of our democratic regimes. Figure 4 below displays these plots for each quartile of the variables. Without any additional controls, civil society and party institutionalization appear to contribute to the survival of a democratic regime. Those democracies with the lowest resources to draw on within each of these institutions, represented by the first and second quartiles in the plots, find themselves exposed to risk and, accordingly, rapidly exit the data set. For those democracies with higher endowments on these institutions, they appear to be offered some protection against shorter lifespans. The pattern displayed in the plots suggest that civil society may be slightly more protective than a well-developed party system, given that we see hardly any exits from the data set was sufficiently high civil society.

Figure 4. Kaplan-Meier Survival Estimates for Civil Society and Party Institutionalization
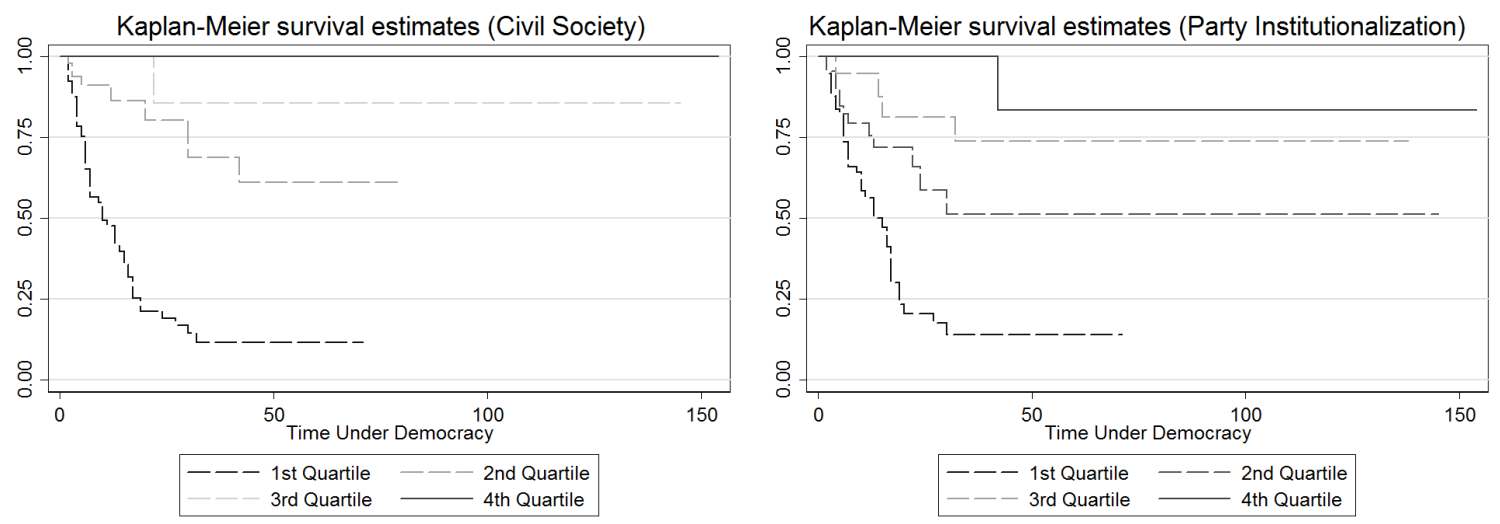

All of the evidence presented above offers support to our account that a robust civil society and a well-developed party system may act as a check against anti-system forces that may threaten to destabilize democracy. But of course, we must control for a variety of potential intervening variables 
that may lead us to falsely reject the null hypothesis. To do this we will estimate our standard and split population event history models with our institutional variables and a set of controls.

As noted above, to take advantage of the V-Dem long temporal coverage and to be able to compare our results against a base model, we use Svolik's (2008) data on control variables. To control for economic development and growth we use Madison's Historical Statistics (2003) to assess both annual GDP per capita (in thousands) and annual GDP growth. In addition to these economic controls we also control for the effect of political institutions. These include a series of dummy variables that capture whether democracy had a Presidential or Parliamentary system. Each of these dummy variables is compared to base category of having a mixed system (again, per Svolik). And whether the Democratic episodes authoritarian legacies had any differential effects on their relative survival. These dummy variables code whether the authoritarian government prior to the democratic episode was headed by the Military, Civilians, or a Monarchy. Each of these dummy variables is compared to the base category of a country not having been independent prior to the transition.

\section{Standard Models}

Table 1, below, displays the models from the standard event history estimators. The Weibull parameterizations are displayed in the first two columns and the Log-Log parameterizations are displayed in the second two columns.

Each of the base models yield results similar to Svolik's (2008) standard models. The estimates are not exact given that our time period only picks up in 1900. However compared to Svolik's simple Log-Log estimation, the inferences are the same: GDP per capita GDP growth and having a military legacy all influence democratic reversals in the expected direction. As a base of comparison for our institutional effects below, it is useful to discuss the size of the insulating effect of wealth on the relative hazards of breakdown. The results above suggest that an additional \$1000 in GDP decrease the relative hazard by $30 \%$. 
Table 1. De mocratic Survival by Civil Society and Party Ins titutionalization

\begin{tabular}{|c|c|c|c|c|}
\hline & \multicolumn{2}{|c|}{ Weibull Models } & \multicolumn{2}{|c|}{$\underline{\text { Log-Log Model }}$} \\
\hline & Base & C.S +P.I. & Base & C.S +P.I. \\
\hline \multicolumn{5}{|l|}{ Reversals } \\
\hline \multirow[t]{2}{*}{ Civil Society } & ---- & $0.0094 * * *$ & ----- & $3.2646 * * *$ \\
\hline & ---- & 0.0060 & ---- & 0.647998 \\
\hline \multirow[t]{2}{*}{ Party Inst. } & --- & $0.0226 * * *$ & ---- & $2.2347 * * *$ \\
\hline & ----- & 0.0235 & ----- & 0.615919 \\
\hline \multirow[t]{2}{*}{$G D P$ per capita } & $0.6303 * * *$ & $0.7001 * * *$ & $0.3166 * * *$ & $0.1507 * * *$ \\
\hline & 0.0910 & 0.0921 & 0.0600 & 0.0576 \\
\hline \multirow[t]{2}{*}{ GDP growth } & $0.9505 * * *$ & $0.9437 * * *$ & $0.0353 * * *$ & $0.0428 * * *$ \\
\hline & 0.0127 & 0.0166 & 0.0087 & 0.009567 \\
\hline \multirow[t]{2}{*}{ Military } & $3.8779 * * *$ & 2.0965 & $-0.5607 *$ & -0.4690 \\
\hline & 1.7904 & 1.2377 & 0.3305 & 0.3043 \\
\hline \multirow[t]{2}{*}{ Civilian } & 1.2695 & 1.2542 & -0.1199 & 0.0593 \\
\hline & 0.6206 & 0.5242 & 0.3848 & 0.340294 \\
\hline \multirow[t]{2}{*}{ Monarchy } & 1.0714 & 0.7186 & 0.0106 & 0.2614 \\
\hline & 0.9315 & 0.4911 & 0.6320 & 0.46434 \\
\hline \multirow[t]{2}{*}{ Parliamentary } & 1.1834 & 0.9424 & -0.1145 & 0.1487 \\
\hline & 0.7060 & 0.5201 & 0.4229 & 0.31925 \\
\hline \multirow[t]{3}{*}{ Presidential } & 1.2418 & 0.6054 & -0.0926 & 0.1850 \\
\hline & 0.6238 & 0.3188 & 0.4096 & 0.328573 \\
\hline & & & --- & --- \\
\hline \multirow[t]{2}{*}{ Constant } & $0.0174 * * *$ & 3.2807 & $2.6887 * * *$ & $-0.9467 *$ \\
\hline & 0.0111 & 2.8296 & 0.5740 & 0.507668 \\
\hline Weibull Shape Parameter (p) & 1.30 & $1.5305 * * *$ & ----- & ---- \\
\hline Log-Log Shape Parameter (p) & --- & ---- & 0.6210 & $0.6210 * * *$ \\
\hline Frailty Variance & $1.73 * * *$ & $1.39 * * *$ & 1.31 & $0.6160 * * *$ \\
\hline$A I C$ & 287.50 & 202.91 & 285.48 & 205.14 \\
\hline$B I C$ & 342.01 & 269.53 & 339.99 & 271.77 \\
\hline Failures & 60 & 60 & 60 & 60 \\
\hline Episodes & 149 & 149 & 149 & 149 \\
\hline Cases & 3157 & 3157 & 3157 & 3157 \\
\hline
\end{tabular}

The civil society and party institutionalization variables are statistically significant in each of the estimations and have relatively strong effects on democratic regime survival. The maximum effect of civil society moving on the V-Dem scale from 0-1, will reduce a democracies relative hazard of breakdown by $99.06 \%$. A more reasonable substantive effect might be enhancing civil society by .2 on our 1 to 0 scale. Such a chance would induce a $60.6 \%$ reduction in the hazard of breakdown - nearly equivalent to the effect of $\$ 2000$ additional

The maximum effect of a democracy having an institutionalized party system, moving on the VDem scale from 0-1, will reduce a democracies relative hazard of breakdown by $97.74 \%$. A more reasonable substantive effect might be enhancing party structures by .2 on our 1 to 0 scale. Such a chance would induce a $53.1 \%$ reduction in the hazard of breakdown - again slightly less than an equivalent effect of adding $\$ 2000$ to GDP.

A quick side note before we move to the split population models. In each of the models above where we estimate the effects of civil society and party institutionalization on democratic regimes stability, the previously significant effect a military legacy of authoritarianism is now null. We believe this is due to the fact that democratic regimes extracting themselves from military authoritarian legacies are less likely to begin their democratic experience with robust civil societies and welldeveloped party institutions (see Geddes and Franz 2007 and Hicken and Kuhonta 2014). In fact, civil society (-.288) and party institutionalization (-.314) are moderately negative correlated with previous military legacy. By including these newly available measures in a standard model democratic 
survival, we have unearthed a potential explanation to the relatively robust finding in the literature that military legacies have negative impacts on democratic regimes.

\section{Split Population Models}

To this point in the analysis we have assumed that every democratic regime is a transitional one, exposed to a potential risk of democratic collapse. Svolik (2008) demonstrated that such an assumption is tenuous, finding strong evidence that democracies split into consolidated and transitional regimes, with the former having low risks of experiencing transition.

To consider this possibility we estimated split population Weibull parameterization. We first estimate a model that replicates Svolik's analysis and then estimate a second model which includes our measures of civil society and party institutionalization. The reversals model is parameterized as a Weibull with time-varying covariates. The consolidation model is parameterized with a logistic link function.

The models are reported in Table 2 below. The first column reports the results of a base model, while the second includes our two institutional measures. The base model is largely similar to that reported by Svolik (2008). His analysis suggested that economic growth was the main driving force behind the timing of democratic reversals and that wealth and having a military legacy with the main drivers behind whether a democracy was considered to be consolidated. Despite our analysis being run on a different time period, 1900 to 2001, our results are quite similar in both statistical significance and substantive impact. 
The second column reports the results from including the civil society and party institutionalization variables as covariates in the reversal and consolidation models. Perhaps the greatest change between the base model and the model in which our institutional variables are included is that there is no longer any evidence that GDP per capita drives the consolidation status of democracy.

Given the robustness of the relationship between level of development and democratic survival in previous work, this is a shocking finding. Given that our first model replicates Svolik's finding, albeit on a smaller sample, we conclude that the failure of development to attain significance in the second model is a product of incorporation of our institutional variables into the regression. Given the low correlations between CCSI and PSI and development reported above, we do not think this is an issue of simple collinearity.

For now we treat this finding as intriguing but tentative. As this line of research is only in its beginning stages we need to do more analysis of the question, paying careful attention to design, model specification, and time period effects before making overarching claims on Table 2. Democratic Survival by Civil Society and Party Institutionalization

\begin{tabular}{ccc} 
& \multicolumn{2}{c}{ Split Population Models } \\
Weibull Parameterization \\
Base & C.S. + P.I. \\
\hline
\end{tabular}

Reversals Model Civil Society

Party Inst.

GDP per capita

GDP growth

Military

Civilian

Monarchy

Parliamentary

Presidential

Intercept

Shape Parameter (p)

Consolidation Model

Civil Society

Party Inst.

GDP per capita

GDP growth

Military

Civilian

Monarchy

Parliamentary

Presidential

Intercept

Frailty Variance

AIC

BIC

Failures

Episodes

Cases

\begin{tabular}{|c|c|c|c|}
\hline --- & & 2.4124 & $* * *$ \\
\hline ---- & & 0.5271 & \\
\hline ---- & & 1.7313 & $* * *$ \\
\hline ---- & & 0.5532 & \\
\hline 0.0490 & & 0.0502 & \\
\hline 0.0924 & & 0.0922 & \\
\hline 0.0491 & $* * *$ & 0.0400 & $* * *$ \\
\hline 0.0191 & & 0.0116 & \\
\hline-0.4411 & & -0.5169 & $* *$ \\
\hline 0.3612 & & 0.2374 & \\
\hline 0.1160 & & -0.0441 & \\
\hline 0.3571 & & 0.2769 & \\
\hline 0.6994 & & 0.3657 & \\
\hline 0.5871 & & 0.4178 & \\
\hline-0.5334 & & -0.1303 & \\
\hline 0.3557 & & 0.2870 & \\
\hline 0.2324 & & 0.3171 & \\
\hline 0.3034 & & 0.0431 & \\
\hline 2.4118 & $* * *$ & 0.2024 & \\
\hline 0.4195 & & 0.5276 & \\
\hline 2.4470 & $* * *$ & 1.7530 & $* * *$ \\
\hline 0.7740 & & 0.2610 & \\
\hline
\end{tabular}

$\begin{array}{ll}-- & 1.3238\end{array}$

$\begin{array}{cc}-- & 3.5124 \\ --- & 16.7715\end{array}$

--- 7.6917

$2.5659 \quad * * \quad 0.6264$

$\begin{array}{ll}2.5659 & 0.4449\end{array}$

$0.2585 \quad 0.1620$

0.2528

$-4.3113 * \quad-0.4670$

$2.3040 \quad 1.4170$

$\begin{array}{ll}-0.5366 & -0.6958\end{array}$

$\begin{array}{ll}1.4624 & 1.3230\end{array}$

$-13.7609 \quad-15.4194$

$614.9107 \quad 830.9160$

$2.0938 \quad 0.9178$

$2.6010 \quad 2.9171$

$-9.7983 *-3.0887$

$5.6953 \quad 3.5163$

$-7.5553 * * \quad-16.1176 * * *$

$3.9407 \quad 6.0579$

$2.4020 \quad 0.0296$

$1.9280 \quad 0.1478$

$525.183 \quad 469.43$

$634.216 \quad 602.69$

$\begin{array}{cc}60 & 60 \\ 148 & 148 \\ 3157 & 3157\end{array}$ the basis of this one finding. While these results are intriguing, it is incumbent on us to demonstrate the robustness of this finding before making any major claims against what has been seen as one of the most unimpeachable and robust findings in the survival literature. 
With respect to our main variables of interest, we see two different patterns. First, both civil society and party institutionalization are statistically significant for the reversal model and have positive time-to-failure coefficients, suggesting that transitional democracies can draw upon these resources to stave off reversals. A transitional democracy with a more entrenched civil society and institutionalized party system is more likely to endure compared to those regimes that lack these resources. Second, party institutionalization also influences whether a democracy is transitional or consolidated.

The substantive effects of these variables are quite strong. For the timing of reversals, we consider the substantive impact of enhancing each of our institutions by .2 on our V-Dem scales of 0 to 1 - a substantive change well within the core of our data. The analysis suggests that democracies with a more entrenched civil society (an additional .2 units) evidence a decrease in their baseline hazard of experiencing a reversal of $-57.08 \%$ and enhances the regime's survival time by $62.01 \%$. The effect of party institutionalization on the timing of reversals is similar although slightly smaller in magnitude. The analysis suggests that democracies with a more institutionalized party system (an additional .2 units) evidence a decrease in their baseline hazard of experiencing a reversal of $-45.50 \%$ and enhances the regime's survival time by $41.38 \%$.

To provide some perspective to the substantive effects consider the effect of economic growth on reversals. Our analysis suggests that an economic contraction of $10 \%$ in the year prior, increases the baseline hazard of experiencing a reversal by $101.62 \%$ and shortens the expected survival time by $32.97 \%$.

Turning to the consolidation model, only institutionalized party systems appear to shape whether a democracy is likely to be consolidated. Civil society has no effect on how these regimes split in the data. Table 3 below displays the substantive effects of how varying levels of party institutionalization

Table 3. Probability of a Consolidated Democracy over Party Institutionalization

Party Institutionalization $\quad$ Pr(Consolidated Democracy)

affect the probability of

\begin{tabular}{ll}
0.65 & 0.0143 \\
0.75 & 0.0739 \\
0.85 & 0.3053 \\
0.95 & 0.7075 \\
\hline
\end{tabular}

the consolidated democracy in the first year. With all the other Notes: Estimates are calculated for other variables held at their median or modal values and for a democracy's first year variables held at the mediator modal values, a well-established and operational party system appears to offer strong information about whether a democracy is consolidated. However, this effect is nonlinear and has its 
strongest effects on enhancing a democracies consolidation prospects only at sufficiently high levels of institutionalization. ${ }^{8}$

\section{Concluding Thoughts}

The distributional model has brought notable advances to the study of regimes and regime transitions. With its econometric approach it has stressed the importance of structural conditions and has paid less attention to role that institutions play, especially in its accounts of the genesis and perpetuation of democratic forms of rule. This is also in part a product of the failure of early institutionalist explanations of democratic survival to produce consistent and robust findings in large-n testing despite well-formulated and reasoned theory. Recent forays into the importance of institutions for authoritarian regimes have reminded us of the potential importance of institutions to regime change and stability. In as much as institutions are the product of explicit human design and action, their incorporation into the literature provides a way to integrate the importance of human agency and decision-making into distributionist accounts.

The collection of global data by the V-Dem project has provided us with an opportunity to integrate two institutional realms identified in meso-level literatures as important to democracy into a more global framework. We identified both civil society and the party systems as potentially crucial areas for democratic survival and theorized about why this might be so within the parameters of a distributionist framework for survival. The tests we framed have produced very encouraging results. In standard models using Weibull and log-log specifications we showed that both party system institutionalization and a developed civil society to be strong covariates of survival.

In a split population model that examined the covariates of at-risk survival and consolidation separately, we found again that developed party systems and civil society insulated transitional democracies from rapidly breaking down. In terms of the consolidation model, looking at the covariates that insulate democracy from risk, party system institutionalization proves to be a significant predictor of consolidaton. Our findings suggest that a very strong level of party system institutionalization around the time of transition represents a very substantial advantage for consolidation. We were surprised by the dropping out of level of development once we include our

\footnotetext{
${ }^{8}$ Note too, that the negative relationship between presidentialism and democratic consolidation in Svolik's original model disappears we when we include PSI. This is consistent with an argument that the effects of presidential on democratic quality and consolidation flow through its effect on the party system (see Samuels and Shugart 2010).
} 
institutional variables. In future work we will turn a great deal of attention to verifying and working to better understand this finding. 


\section{References}

Acemoglu, D. and Robinson J. (2006).Economic Origins of Dictatorship and Democracy. Cambridge: Cambridge University Press.

Adler, G., \& Webster, E. (1995). Challenging Transition Theory: The Labor Movement, Radical Reform, and Transition to Democracy in South Africa. Politics and Society, 25(1), 75-106.

Aleman, J., \& Yang, D. D. (2011). A Duration Analysis of Democratic Transitions and Authoritarian Backslides. Comparative Political Studies, 44(9), 1123-1151.

Almond, G., \& Verba, V. S. (1963). The Civic Culture: Political Attitudes and Democracy in Five Nations. Princeton: Princeton University Press.

Arato, A. (1993). Civil Society and the State, Poland 1980-81. In A. Arato, From Neo-Marxism to Democratic Theory (pp. 171-211. ). Armonk: M.E. Sharpe.

Basedau, M. (2007). Do party systems matter for democracy. Votes, money and violence. Political parties and elections in Africa, Uppsala: Nordic Africa Institute, 105-143.

Basedau, M., \& Stroh, A. (2011). Do Party Systems Make Democracy Work? A Comparative Test of Party-system Characteristics and Democratization in Francophone Africa. In Regression of Democracy? (pp. 173-199). VS Verlag für Sozialwissenschaften.

Berman, S. (1997). Civil Society and the Collapse of the Weimar Republic. World Politics, 59, 401-429.

Bernhard, M. (1993). Civil Society and Democratization in East-Central Europe. Political Science Quarterly, 108(2), 307-326.

Bernhard, M., \& Karakoç, E. (2007). Civil Society and the Legacies of Dictatorship. World Politics, 59(4), 539-567.

Bernhard, M., Nordstrom, T., \& Reenock, C. (2001). Economic Performance, Institutional Intermediation, and Democratic Survival. Journal of Politics, 63, 775-803.

Bernhard, M., Reenock, C., \& Nordstrom, T. (2003). Economic Performance and Survival in New Democracies: Is There a Honeymoon Effect? Comparative Political Studies, 36, 404-431. 
Bértoa, F. (2009). Party system institutionalisation and the Quality of Democracy in Eastern Europe. DISC WP, (7), 32.

Boix, Carles, (2003). Democracy and Redistribution. Cambridge: Cambridge University Press.

Boix, C., Miller, M., \& Rossato, S. (2013). A Complete Data Set of Political Regimes, 1800-2007. Comparative Political Systems, 46(12), 1523-1554 .

Booth, J. A., \& Richard, P. B. (1998). Civil Society, Political Capital, and Democratization in Central America. Journal of Politics, 60(3), 780-800.

Bratton, M., \& Van de Walle, N. (1997). Democratic Experiments in Africa. New Yoirk: Cambridge University Press.

Chambers S. and Kopstein, J. (2001). Bad Civil Society," Political Theory, 29(6), 838-866.

Cheibub, J. A. (2007). Presidentialism, Parliamentarism, and Democracy. New York: Cambridge University Press.

Collier, R. B., \& Collier, D. (1991). Shaping the Political Arena: Critical Junctures, the Labor Movement, and Regime Dynamics in Latin America. Princeton: Princeton University Press.

Coppedge, M. (1994). Strong Parties and Lame Ducks: Presidential Partyarchy and Factionalism in Venezuela. Stanford: Stanford University Press.

Coppedge, Michael, John Gerring, Staffan I. Lindberg, Jan Teorell, David Altman, Michael Bernhard, M. Steven Fish, Adam Glynn, Allen Hicken, Carl Henrik Knutsen, Matthew Kroenig, Kelly McMann, Daniel Pemstein, Megan Reif, Svend-Erik Skaaning, Jeffrey Staton, Eitan Tzelgov, Yi-ting Wang. 2014. "Varieties of Democracy Codebook v1". Varieties of Democracy Project: Project Documentation Paper Series.

Dahl, R. (1971). Polyarchy. . New Haven: Yale University Press,

Dix, R. H. (1992). Democratization and the institutionalization of Latin American political parties. Comparative Political Studies, 24(4), 488-511.

Doyle, D. (2011). The Legitimacy of Political Institutions Explaining Contemporary Populism in Latin America. Comparative Political Studies, 44(11), 1447-1473. 
Edwards, B., \& Foley, R. W. (1998). Civil Society and Social Capital Beyond Putnam. American Behavioral Scientist, 42(1), 124-139.

Ekiert, G., \& Kubik, J. (1998). Contentious Politics in New Democracies: East Germany, Hungary, Poland, and Slovakia, 1989-93. World Politics, 50(4), 547-581.

Encarnación, O. G. (2003). The Myth of Civil Society: Social Capital and Democratic Consolidation in Spain and Brazil. New York: Palgrave Macmilllian.

Fernandes, T. (2015). Rethinking Pathways to Democracy: Civil Society in Portugal and Spain, 1960s-2000s. Democratization. doi:10.1080/13510347.2014.901966

Gasiorowski, M. J. (1995). "Economic Crisis and Political Regime Change: An Event History Analysis. The American Political Science Review, 89, 882-897.

Gandhi, J. (2008). Political Institutions under Authoritarianism, Cambridge: Cambridge University Press.

Geddes, B. \& Frantz, E. (2007). The Effect of Dictatorships on Party Systems in Latin America. Unpublished manuscript, UCLA.

Hicken, A. (2011). Coming up Short? Party System Institutionalization in Southeast Asia. In The Crisis of Democratic Governance in Southeast Asia. Aurel Croissant and Marco Bünte eds. Palgrave.

Hicken, A. and Kuhonta, E. M. (2014.) Rethinking Party System Institutionalization in Asia. In A. Hicken and E.M. Kuhonta (Eds), Party and Party System Institutionalization in Asia: Democracies, Autocracies and the Shadows of the Past. New York: Cambridge University Press

Howard, M. (2003). The Weakness of Civil Society in Post-Communist Europe. Cambridge: Cambridge University Press.

Huntington, S. P. (1968). Political Order in Changing Societies. New Haven: Yale University Press.

Inglehardt, R., \& Welzel, C. (2005). Modernization, Cultura lChange, and Democracy: the Human Development Sequence. New York: Cambridge University Press.

Kaufman, R. R. (2008, April). The political left, the export boom, and the populist temptation. Paper presented at Latin America's Left Turn, Cambridge, MA. 
Kneuer, M. (2013). Deficits in Democratic Quality? The Effects of Party-System Institutionalisation on the Quality of Democracy in. Regression of Democracy?, (1), 133.

Lai, B., \& Melkonian-Hoover, R. (2005). Democratic Progress and Regress:The Effect of Parties on the Transitions of States to and Away from Democracy. Political Research Quarterly, 58(4), pp. 551-564.

Levitsky, S. (1998). Institutionalization and Peronism. Party Politics 4(1): 77-92.

Lewis, P. G. (2006). Party systems in post-communist Central Europe: patterns of stability and consolidation. Democratization, 13(4), 562-583.

Linz, J. (1978). The Breakdown of Democratic Regimes: Crisis, Breakdown and Reequilibration. Baltimore: Johns Hopkins University Press.

Linz, J. (1994). Presidential or Parliamentary Democracy: Does it make a difference? In J. Linz, \& A. Valenzuela, The Failure of Presidential Democracy: Comparative Perspectives (pp. 3-88). The Johns Hopkins Press.

Linz, J., \& Stepan, A. (1996). Problems of Democratic Transition and Consolidation: Southern Europe, South America, and Post-Communist Europe. Baltimore: Johns Hopkins University Press.

Luebbert, G. M. (1991). Liberalism, Fascism, or Social Democracy: Social Classes and the Political Origns of Regimes in Interwar Europe. New York: Oxford.

Maeda, K. (2010). Two Modes of Democratic Breakdown: A Competing Risks Analysis of Democratic Durability. The Journal of Politics, 72(4), 1129-1143.

Mainwaring, S. (1998). Party systems in the third wave. Journal of Democracy, 9(3), 67-81.

Mainwaring, S. (1999). Rethinking Party Systems in the Third Wave of Democratization: The Case of Brazil. Stanford: Stanford University Press.

Mainwaring, S., \& Pérez-Liñán, A. (2014). Democracies and Dictatorships in Latin America: Emergence, Survival, and Fall. New York: Cambridge University Press.

Mainwaring, S. and Scully, T. (Eds.). (1995). Building Democratic Institutions: Party Systems in Latin America. Stanford: Stanford University Press. 
Mainwaring, S., \& Shugart, M. (1997). Conclusion: Presidentialism and the Party System. In S. Mainwaring, \& M. Shugart (Eds.), Presidentialism and Democracy in Latin America (pp. 394-439). New York: Cambridge.

Mainwaring, S. and Torcal, M. 2006. Party System Institutionalization and Party System Theory After the Third Wave of Democratization. In R.S. Katz \& W. Crotty (Eds.), Handbook of Political Parties (pp. 204-227). London: Sage.

Markowski, R. (2001). Party System Institutionalization in New Democracies: Poland-a Trend Setter with no followers. Paul G. Lewis (szerk.) Party Development and Democratic Change in Post-communist Europe, 55-77.

McGuire, J. W. (1997). Peronism without Perón: Unions, parties, and democracy in Argentina (p. 252). Stanford: Stanford University Press.

Newton, K. (2001). Trust, Social Capital, Civil Society, and Democracy. International Political Science Review, 22(2), 201-214.

North, D. C., Summerhill, W., \& Weingast, B. (2000). Order, Disorder, and Economic Change: Latin America versus North America. In B. Buena de Mesquita, \& H. Root (Eds.), Governing for Prosperity. New Haven: Yale University Press.

O'Donnell, G. (1999). Delegative Democracy, Counterpoints: Selected Essays on Authoritarianism and Democratization, Notre Dame: Notre Dame University Press, 159-174.

O'Donnell, G., \& Schmitter, P. C. (1986). Tentative Conclusions about Uncertain Democracies. In G. O'Donnell, \& P. C. Schmitter, Transitions from Authoritarian Rule (Vol. 4, pp. 1-72). Baltimore: Baltimore.

Osei, A. (2013). Party System Institutionalization in Ghana and Senegal. Journal of Asian and African Studies, 48(5), 577-593.

Panebianco, A. (1988). Political Parties: Organization and Power. Cambridge: Cambridge University Press.

Pop-Eleches, G., \& Tucker, J. (2013). Associated with the Past? : Communist Legacies and Civic Participation in Post-Communist Countries. East European Politics and Societies, 27(1), 45-68. 
Power, T. J., \& Gasiorowski, M. J. (1997). Institutional Design and Democratic Consolidation in the Third World. Comparative Political Studies, 30(2), pp. 123-155.

Przeworski, A. (1991). Democracy and the Market. Cambridge: Cambridge University Press.

Przeworski, A. (2004). Institutions Matter? Government and Opposition, 39(2), pp. 527-540.

Przeworski, A. (2005). Democracy as an Equilibrium. Public Choice, 123(3-4), pp. 253-273.

Przeworski, A., Alvarez, M. E., Cheibub, J. A., \& Limongi, F. (2000). Development and Democracy. New York: Cambridge.

Putnam, R. (1993). Making Democracy Work. Civic Traditions in Modern Italy. Princeton: Princeton University Press.

Putnam, R. D. (2000). Bowling Alone: The Collapse and Revival of American Community. New York: Simon \& Schuster.

Randall, V. and Svasand, L. (2002). Party Institutionalization in New Democracies. Party Politics, 8(1): 5-29.

Reenock, C. Staton, J. and Radean, M. 2013. Legal Institutions and Democratic Survival. Journal of Politics 95 (2): 491-505.

Reidl, Rachel. B. (2014). Authoritarian Origins of Democratic Party Systems: Power in Transition in Africa. Cambridge: Cambridge University Press.

Riley, D. J. (2010). The Civic Foundations of Fascism in Europe: Italy, Spain, and Romania 1870-1945. Baltimore: Johns Hopkins University Press.

Roberts, K. M. (1998). Deepening democracy?: the modern left and social movements in Chile and Peru. Stanford University Press.

Roberts, K. M. (2007). Latin America’s populist revival. SAIS Review, 27(1), 3-15.

Rothstein, B. (2005). Social Traps and the Problem of Trust. New York: Cambridge University Press.

Rueschemeyer, D., Stephens, J., \& Stephens, E. H. (1992). Capitalist Development and Democracy. Chicago: University of Chicago Press. 
Rupnik, J. (1979). Dissent in Poland, 1968-78: The End of Revisionism and the Rebirth of Civil Society. In R. L. Tőkés, Opposition in Eastern Europe. Baltimore: Johns Hopkins University Press.

Sartori, G. (1976). Parties and Party Systems. New York: Cambridge University Press.

Schamis, H. (2006). Populism, socialism and democratic institutions. Journal of Democracy, 17(4), 2034.

Schedler, A. (1998). What is Democratic Consolidation? Journal of Democracy 9(2), 91-107..

Schedler, A. (2013). The Politics of Uncertainty: Sustaining and Subverting Electoral Authoritarianism. New York: Oxford University Press.

Seligson, M., \& Mueller, E. (1994). Civic Culture and Democracy:The Question of Causal Relationships. American Political Science Review, 42, 635-654.

Shugart, M. S., \& Carey, J. M. (1992). Presidents and Assemblies: Constitutional Design and Electoral Dynamics. New York: Cambridge University Press.

Sing, M. (2010). Explaining Democratic Survival Globally (1946-2002). Journal of Politics, 72(2), pp. $438-455$.

Skocpol, T. (2011). Civil Society in the United States. In M. Edwards, The Oxford Handbook of Civil Society (p. .). New York: Oxford University Press.

Skocpol, T., \& Fiorina, M. (1999). Civic Engagement in American Democracy. Washington, D.C.: Brookings Instittuion Press.

Stepan, A. (1985). State Power and the Strength of Civil Society in the Southern Cone of Latin America. In P. B. Evans, D. Rueschemeyer, \& T. Skocpol, Bringing the State Back In (pp. 317-346). Cambridge: Cambridge University Press.

Stockton, H. (2001). Political Parties, Party Systems, and Democracy in East Asia Lessons from Latin America. Comparative Political Studies, 34(1), 94-119.

Svolik, M. (2008). Authoritarian Reversals and Democratic Consolidation. American Political Science Review, 102(2), 153-168. 
Svolik, M. (2012). The Politics of Authoritarian Rule. Cambridge: Cambridge University Press.

Tóka, G. (1997). Political parties and democratic consolidation in East Central Europe (No. 279). Centre for the Study of Public Policy, University of Strathclyde.

Ufen, A. 2008. olitical Party and Party System Institutionalization in Southeast Asia: Lessons for Democratic Consolidation in Indonesia, the Philippines and Thailand." The Pacific Review 21(3):327350.

Ufen, A. (2012). Party Systems, Critical Junctures, and Cleavages in Southeast Asia. Asian Survey 52(3): 441-464.

Wallis, D. (2003). Democratizing a hegemonic regime: From institutionalized party to institutionalized party system in Mexico?. Democratization, 10(3), 15-38.

Weyland, K. (2009). The rise of Latin America's two lefts? Insights from rentier state theory. Comparative Politics, 41, 145-164. 